\title{
Identification of Leaf Rust Resistance Genes in Selected Egyptian Wheat Cultivars by Molecular Markers
}

\author{
I. A. Imbaby, ${ }^{1}$ M. A. Mahmoud, ${ }^{1}$ M. E. M. Hassan, ${ }^{1}$ and A. R. M. Abd-El-Aziz ${ }^{2}$ \\ ${ }^{1}$ Plant Pathology Research Institute, Agricultural Research Center, Giza 12619, Egypt \\ ${ }^{2}$ Botany and Microbiology Department, College of Science, King Saud University, Riyadh 1145, Saudi Arabia \\ Correspondence should be addressed to M. A. Mahmoud; m.a.mahmoud75@gmail.com
}

Received 9 October 2013; Accepted 21 November 2013; Published 6 January 2014

Academic Editors: Y. Saintigny and D. Smeets

Copyright (c) 2014 I. A. Imbaby et al. This is an open access article distributed under the Creative Commons Attribution License, which permits unrestricted use, distribution, and reproduction in any medium, provided the original work is properly cited.

\begin{abstract}
Leaf rust, caused by Puccinia triticina Eriks., is a common and widespread disease of wheat (Triticum aestivum L.) in Egypt. Host resistance is the most economical, effective, and ecologically sustainable method of controlling the disease. Molecular markers help to determine leaf rust resistance genes ( $L r$ genes). The objective of this study was to identify $L r$ genes in fifteen wheat cultivars from Egypt. Ten genes, Lr13, Lr19, Lr24, Lr26, Lr34, Lr35 Lr36, Lr37, Lr39, and Lr46, were detected in fifteen wheat cultivars using various molecular markers. The most frequently occurring genes in fifteen Egyptian wheat cultivars were $\operatorname{Lr} 13, \operatorname{Lr} 24, \operatorname{Lr} 34$, and $\operatorname{Lr} 36$ identified in all the cultivars used, followed by $\operatorname{Lr} 26$ and $\operatorname{Lr} 35$ (93\%), $\operatorname{Lr} 39$ (66\%), $\operatorname{Lr} 37$ (53\%), and $\operatorname{Lr} 46$ (26.6\%) of the cultivars, and finally $\operatorname{Lr} 19$ was present in $33.3 \%$ of cultivars. It is concluded that there was a good variation in $\operatorname{Lr}$ genes carried by wheat cultivars commercially grown in Egypt. Therefore, strategies for deploying resistance genes to prolong effective disease resistance are suggested to control wheat leaf rust disease.
\end{abstract}

\section{Introduction}

Rusts are the most devastating fungal diseases posing a threat to wheat production worldwide. Leaf rust, caused Puccinia triticina Eriks., is a major disease in most of the wheatgrowing areas [1]. In Egypt, leaf rust is the most common and important wheat disease. It caused severe losses in grain yield which reached 23\% [2] and losses in epidemic years reached up to $50 \%$ [3]. The most environmentally sound, low cost method of controlling leaf rust is to breed and grow resistant wheat varieties. So far over 60 leaf rust resistance genes, that is, $L r$ genes, have been identified and localized on the wheat chromosomes [4]. Resistance genes are expressed at seedling stage (qualitative resistance genes) than at adult plant (quantitative resistance genes). Certain adult plant resistance genes like Lr34 and Lr46 are very important for breeding because they proved to confer durable resistance over a long period of time in different environments, as well as against diverse pathotypes of the fungus [5].

The effectiveness of resistance genes depends on the composition of the pathogen populations. As this changes dynamically, new pathotypes virulent to the given resistance genes multiply from time to time, so the resistance of a variety is not a constant trait. A variety carrying a single resistance gene mat becomes susceptible within a short time. The postulation of resistance genes is traditionally carried out using rust isolates with known virulence [6] but this procedure is extremely time, space, and labour intensive and cannot be employed if no different fungal isolates are available. In many cases resistance genes can only be identified using molecular markers [7]. Over the last 15 years many efficient markers for leaf rust resistance genes have been described. The molecular markers most closely linked to $L r$ genes are based on the PCR technique, as the majority of these can be applied relatively easily in wheat breeding programmers.

Molecular markers are used for two purposes in resistance breeding: (1) to monitor the incorporation of designated resistance genes or QTLs into elite wheat genotypes (i.e., MAS, marker-assisted selection) and (2) to identify resistance genes in varieties and lines where the genetic background is unknown (i.e., gene detection). A great deal of information on postulated leaf rust resistance genes has 
been collected from countries (including Australia, Canada, China, India, Pakistan, South Africa, and USA) where wheat is a major crop [8-12]. Little information is available on $\mathrm{Lr}$ genes present in Egyptian wheat cultivars $[13,14]$.

Objective of this study is to identify genes for resistance to leaf rust disease in selected Egyptian wheat cultivars.

\section{Materials and Method}

2.1. Plant Material. Fifteen wheat cultivars were used. These cultivars were tested for leaf rust disease under green house at seedling and adult plant stages. Fifteen Egyptian wheat cultivars and seven Near-Isogenic Thatcher lines (NILs) were tested for wheat leaf rust for their reaction to leaf rust. The wheat cultivars include Giza cultivars $(163,164,165,167$, and 168), Sakha cultivars $(8,61,69,92$, and 94$)$, Sids cultivars (1 and 12) and Gemmeiza cultivars (7, 9, and 10). The selected Thatcher NILs were Lr13, Lr19, Lr24, Lr26, Lr34, Lr37, Lr36, and $\operatorname{Lr} 49$.

\subsection{Disease Assessment}

2.2.1. Seedling Stage. The cultivars to be tested were planted in $7 \mathrm{~cm}$ square plastic pots. Four cvs were planted per pot with 10-15 seeds per cv planted in each corner of the pot. Plants were grown in rust-free greenhouse until inoculation. At 7 days after planting when first leaves were fully expanded, the seedlings were gently rubbed between moist fingers and then sprayed with tap water using atomizer in the inoculation chamber, then inoculated by spraying them with a suspension of urediospores in a light mineral oil carrier. Inoculum concentration was normalized to $2-3 \mathrm{mgmL}^{-1}$ [15]. The oil was allowed to evaporate from the leaves for 30-60 min, and the seedlings were placed overnight in a dew chamber at $17^{\circ} \mathrm{C}$. They were then transferred to a greenhouse with mean temperature approximately $20-21^{\circ} \mathrm{C}$. At 14 days after inoculation, the cvs were scored for infection type (IT) according to the scale of [16], where 0: nearly immune; 1 : very resistant; 2 : moderately resistant; 3 : moderately resistant to moderately susceptible; and 4: very susceptible.

2.2.2. Adult Stage. The aforementioned cvs were sown in $30 \mathrm{~cm}$ square diameter pots. Each cv was planted in each pot, and four pots were planted for each $\mathrm{cv}$ as replicates. 75 days after planting (prebooting stage) [17], the plants were inoculated as mentioned before. After incubation, the plants were transferred onto the greenhouse benches. The disease severity (\%) was recorded as the area of leaf covered with rust pustules according to the method adopted by [16]. Moreover, the particular cvs were planted in $25 \mathrm{~cm}$ square diameter pots and were left till tillering stage [17] then harvested for gene identification by using molecular markers.

2.3. DNA Extraction. DNA was isolated from 50 of the varieties (each) using Qiagen kit for DNA extraction. The extracted DNA was dissolved in 100 ul of elution buffer. The concentration and purity of the obtained DNA were determined by using "Gen Qunta" system, pharmacia Biotech. The purity of the DNA for all samples was between 90 and $97 \%$ and the ratio between 1.7 and 1.8 concentrations was adjusted at $6 \mathrm{ng} / \mathrm{ul}$ for all samples using TE buffer $\mathrm{pH}$ 8.0.

2.4. Detection of Lr Genes by Molecular Markers. Thirty ng from the extracted DNA, $0.25 \mu \mathrm{M}$ of each primer of its and $0.40 \mu \mathrm{M}$ from each specific primer (10 primers) were used for amplification reaction. The PCR mixture contained PCR beads tablet (manufactured by Amesshan Pharmacia Biotech) which contained all of the necessary reagents except the primer and the DNA to be used. The total volume was completed to $25 \mu \mathrm{L}$ using sterile distilled water. The sequences of the used primers and size fragment are present in Table 3. Amplifications were performed in T-gradient thermocycler (Biometra, Germany). Sequences of primers are listed in Table 1. Amplification parameters for all primer sets used are presented in Table 2.

2.5. Electrophoresis. Amplification products were separated with 2\% agarose gel (Applichem, Germany) in 1x TBE buffer and stained with ethidium bromide $(0.5 \mu \mathrm{g} / \mathrm{mL})$. The $10 \mu \mathrm{L}$ PCR products were combined with $3 \mu \mathrm{L}$ of loading buffer, which was added to prepare samples for agarose gel electrophoresis. PCR products were electrophoresed at 75 volt using an electrophoresis unit (WIDE mini-sub cell GT Bio$\mathrm{Rad}$ ), and determined with UV transilluminator.

2.6. Gel Analysis. The DNA was scanned for band Rf using gel documentation system (AAB Advanced American Biotechnology 1166E. Valencia Dr. Unit 6 c, Fullerton CA 92631). The different MW bands were determined against PCR marker Promega G 452150 bp DNA step ladder and Amresco 100 bp k180 by unweighted pair-group method based on arithmetic mean (UPGMA).

\section{Results}

3.1. Tested Cultivars and Resistance to Leaf Rust Disease. Resistance of the fifteen wheat cultivars to leaf rust isolates at seedling and adult plant stages is shown in Table 3. Some cultivars, that is, Giza 168, Sakha 94, and Gemmeiza 9, showed resistance at both stages; meanwhile, Giza 163, Giza 164, Giza 165, Sakha 69, and Gemmeiza 10 were resistant at seedling but susceptible at adult plant stage. The rest of the cultivars, that is, Sakha 61, Sakha 92, Sids 1, and Gemmeiza 7, were susceptible at both stages.

3.2. Leaf Rust Resistance Gene Efficacy. The efficiency of wheat genotypes carrying designated $\operatorname{Lr}$ genes, that is, $\operatorname{Lr} 13$, Lr19, Lr24, Lr26, Lr34, Lr35, Lr36, Lr37, Lr39, and Lr46, was estimated at seedling and adult plant stages (Table 4). The result indicated that none of the tested $\mathrm{Lr}$ genes were effective. At adult stage (under field conditions) Lr34 (efficacy 100\%) was the most effective gene, followed by Lr39 (85\%), then Lr19 (75\%) and $L r 46$ (60\%). Lr's 13, 24, 26, and 37 were not effective under the Egyptian conditions. 
TABLE 1: Sequences of the nucleotide primers used in this study.

\begin{tabular}{|c|c|c|c|}
\hline $\operatorname{Lr}$ gene & Primer code & Sequence of primers $\left(5^{\prime}-3^{\prime}\right)$ & $\begin{array}{c}\text { Size of amplified } \\
\text { marker fragment (bp) }\end{array}$ \\
\hline \multirow{2}{*}{13} & $13 \mathrm{~F}$ & GTGCCTGTGCCATCGTC & 324 \\
\hline & $13 \mathrm{R}$ & CGAAAGTAACAGCGCAGTGA & {$[31]$} \\
\hline \multirow{2}{*}{19} & $19 \mathrm{~F}$ & CATCCTTGGGGACCTC & 300 \\
\hline & $19 \mathrm{R}$ & CCAGCTCGCATACATCCA & {$[32]$} \\
\hline \multirow{2}{*}{24} & $24 \mathrm{~F}$ & TCTAGTCTGTACATGGGGGC & 100 \\
\hline & $24 \mathrm{R}$ & TGGCACATGAACTCCATACG & {$[33]$} \\
\hline \multirow{2}{*}{26} & $26 \mathrm{~F}$ & CATCCTTGGGGACCTC & 260 \\
\hline & $26 \mathrm{R}$ & CCAGCTCGCATACATCCA & {$[34]$} \\
\hline \multirow{2}{*}{34} & $34 \mathrm{~F}$ & GTGAAGCAGACCCAGAACAC & 253 \\
\hline & $34 \mathrm{R}$ & GACGGCTGCGACGTAGAG & [35] \\
\hline \multirow{2}{*}{35} & $35 \mathrm{~F}$ & AGAGAGAGTAGAAGAGCTGC & 252 \\
\hline & $35 \mathrm{R}$ & AGAGAGAGAGCATCCACC & {$[36]$} \\
\hline \multirow{2}{*}{36} & $36 \mathrm{~F}$ & GCTGCATGAGCTCTGCAAT & 282 \\
\hline & $36 \mathrm{R}$ & TCTGTGAGGCATGACAGAA & {$[37]$} \\
\hline \multirow{2}{*}{37} & $37 \mathrm{~F}$ & AGGGGCTACTGACCAAGGCT & 199 \\
\hline & $37 \mathrm{R}$ & TGCAGCTACAGCAGTATGTACACAAAA & {$[38]$} \\
\hline \multirow{2}{*}{39} & $39 \mathrm{~F}$ & CCTGCTCTGCCCTAGATACG & 180 \\
\hline & $39 \mathrm{R}$ & ATGTGAATGTGATGCATGCA & {$[39]$} \\
\hline \multirow{2}{*}{46} & $46 \mathrm{~F}$ & AGG GAAAAGACATCTTTTTTT TC & 335 \\
\hline & $46 \mathrm{R}$ & CGACCGACTTCGGGTTC & [35] \\
\hline
\end{tabular}

TABle 2: Amplification parameters for all primer sets used.

\begin{tabular}{|c|c|}
\hline Lr gene & Cycle condition \\
\hline 13 & $\begin{array}{l}94^{\circ} \mathrm{C} 5 \mathrm{~min} ., 30 \text { cycles }\left(94^{\circ} \mathrm{C} 1.5 \mathrm{~min} ., 55^{\circ} \mathrm{C} 2 \mathrm{~min} . \text {, }\right. \\
72^{\circ} \mathrm{C} 1.5 \text { min.), } 72^{\circ} \mathrm{C} 5 \text { min. }\end{array}$ \\
\hline 19 & $\begin{array}{l}94^{\circ} \mathrm{C} 4 \text { min., } 40 \text { cycles }\left(92^{\circ} \mathrm{C} 1 \mathrm{~min} ., 60^{\circ} 1 \mathrm{~min} .\right. \\
\left.72^{\circ} \mathrm{C} 2 \mathrm{~min} .\right), 72^{\circ} \mathrm{C} 5 \mathrm{~min} .\end{array}$ \\
\hline 24 & $\begin{array}{l}94^{\circ} \mathrm{C} 5 \text { min., } 30 \text { cycles }\left(94^{\circ} \mathrm{C} 1.5 \text { min., } 55^{\circ} \mathrm{C} 2 \text { min., }\right. \\
\left.72^{\circ} \mathrm{C} 1.5 \text { min. }\right), 72^{\circ} \mathrm{C} 5 \text { min. }\end{array}$ \\
\hline 26 & $\begin{array}{l}94^{\circ} \mathrm{C} 2 \text { min., } 35 \text { cycles ( } 94^{\circ} \mathrm{C} 30 \text { s., } 63^{\circ} \mathrm{C} 2 \text { min., } \\
72^{\circ} \mathrm{C} 1.5 \text { min.), } 72^{\circ} \mathrm{C} 5 \text { min. }\end{array}$ \\
\hline 34 & $\begin{array}{l}94^{\circ} \mathrm{C} 5 \text { min., } 35 \text { cycles }\left(94^{\circ} \mathrm{C} 30 \text { s., } 65^{\circ} \mathrm{C} 2 \text { min., }\right. \\
\left.72^{\circ} \mathrm{C} 2 \text { min. }\right), 72^{\circ} \mathrm{C} 5 \text { min. }\end{array}$ \\
\hline 35 & $\begin{array}{l}94^{\circ} \mathrm{C} 10 \text { min., } 35 \text { cycles }\left(94^{\circ} \mathrm{C} 1 \text { min., } 54^{\circ} \mathrm{C} 1 \text { min., }\right. \\
\left.72^{\circ} \mathrm{C} 2 \text { min. }\right), 72^{\circ} \mathrm{C} 5 \text { min. }\end{array}$ \\
\hline 36 & $\begin{array}{l}94^{\circ} \mathrm{C} 5 \text { min., } 35 \text { cycles }\left(94^{\circ} \mathrm{C} 1 \text { min., } 57^{\circ} \mathrm{C} 1 \text { min., }\right. \\
\left.72^{\circ} \mathrm{C} 2 \text { min. }\right), 72^{\circ} \mathrm{C} 5 \text { min. }\end{array}$ \\
\hline 37 & $\begin{array}{l}94^{\circ} \mathrm{C} 10 \mathrm{~min} ., 40 \text { cycles }\left(94^{\circ} \mathrm{C} 1 \mathrm{~min} ., 55^{\circ} \mathrm{C} 1 \mathrm{~min} .\right. \\
\left.72^{\circ} \mathrm{C} 1 \mathrm{~min} .\right), 72^{\circ} \mathrm{C} 10 \mathrm{~min} .\end{array}$ \\
\hline 39 & $\begin{array}{l}94^{\circ} \mathrm{C} 4 \mathrm{~min} ., 10 \text { cycles }\left(94^{\circ} \mathrm{C} 1 \mathrm{~min} ., 64^{\circ} \mathrm{C} 1 \mathrm{~min} .\right. \\
\left.72^{\circ} \mathrm{C} 1 \mathrm{~min} .\right), 30 \text { cycles } 94^{\circ} \mathrm{C} 1 \mathrm{~min} ., 55^{\circ} \mathrm{C} 1 \mathrm{~min} . \\
\left.72^{\circ} \mathrm{C} 1 \mathrm{~min} .\right), 72^{\circ} \mathrm{C} 5 \mathrm{~min} .\end{array}$ \\
\hline 46 & $\begin{array}{l}94^{\circ} \mathrm{C} 4 \text { min., } 40 \text { cycles }\left(94^{\circ} \mathrm{C} 1 \text { min., } 58^{\circ} \mathrm{C} 1 \text { min., }\right. \\
72^{\circ} \mathrm{C} 1 \text { min.), } 72^{\circ} \mathrm{C} 10 \mathrm{~min} .\end{array}$ \\
\hline
\end{tabular}

3.3. Detection of Lr Genes with Molecular Markers. 15 wheat cultivars, Giza (163, 164, 165, and 168), Sakha $(8,61,69$, 92, and 94), Sedes (1 and 2) and Gemmeiza (7, 9, and 10), were examined by using molecular markers for ten $\mathrm{Lr}$ genes
(Lr13, Lr19, Lr24, Lr26, Lr34, Lr35, Lr36, Lr37, Lr39, and L 46) against the fungal pathogen of wheat (Figure 1). The size of amplified marker fragment is shown in Table 5 as $\operatorname{Lr} 13,19,24$, 26, 34, 35, 36, 37, 39, and 46 for 324 bp, 300 bp, 100 bp, $260 \mathrm{bp}$, 253 bp, 252 bp, 282 bp, 199 bp, 180 bp, and 335 bp, respectively. Data presented in Table 5 illustrates leaf rust resistance genes identified in the used selected cultivars. using molecular markers. Genes Lr13, Lr24, Lr34, and Lr36 were identified in all the cultivars used. Lr26 was identified in 93\% also, $\operatorname{Lr} 35$ get same present, $\operatorname{Lr} 39$ was identified in $66 \%$ of the materials followed by $\operatorname{Lr} 37$ ( $53 \%$ of the materials). $L r 46$ was present in $26.6 \%$ of the cultivars and finally $\operatorname{Lr} 19$ was present in $33.3 \%$ of cultivars.

\section{Discussion}

Survey for wheat leaf rust in Egypt during many growing seasons, 2000-2012, indicated the presence of the disease incited by $P$. triticina in different governorates. Most of diseased samples were collected from farmer fields and trap nurseries $[13,14,18,19]$. One of the most important steps in breeding programs for rust resistance in wheat is the identification of the prevailing physiological races in the region. Such program will be successful if all physiological isolates of the disease are included [9].

In recent years developments in molecular marker techniques and marker identification have facilitated the spread of molecular-assisted selection (MAS). This is particularly true in the field of breeding wheat for leaf rust resistance, 
TABLE 3: Wheat cultivars tested at seedling and adult plant stages for resistance to leaf rust disease.

\begin{tabular}{|c|c|c|c|}
\hline \multirow{2}{*}{ Cultivar } & \multirow{2}{*}{ Pedigree } & \multicolumn{2}{|c|}{ Resistance to leaf rust disease } \\
\hline & & Seedling ${ }^{\mathrm{a}}$ & Adult $^{\mathrm{b}}$ \\
\hline Giza 163 & T.aestivum/Bom/Ciano/3/Siete Cerros & 1,2 & $50 \mathrm{~S}$ \\
\hline Giza 164 & Kavkas/Buho"s"//Kal/Bluebird=Verry\#5 & 1 & $80 \mathrm{~S}$ \\
\hline Giza 165 & Ciano/Maris Fundin//Mantaro & 2,3 & $90 \mathrm{~S}$ \\
\hline Giza 167 & $\mathrm{Au} / \mathrm{Up}$ 301//GII/Sx/3/Pew "s"/4/Mai “s"/Maya "s"//Pew & 3 & $50 \mathrm{~S}$ \\
\hline Giza 168 & MRL/BUC//Seri.CM93046-8M-0Y-0M-2Y-0B & 2 & $20 \mathrm{MR}$ \\
\hline Sakha 8 & Indus/Norteno "s" & 0,1 & $10 \mathrm{MSS}$ \\
\hline Sakha 61 & Inia-RL 4220//Siete Cerros/Yaqui 50 & 3 & $50 \mathrm{~S}$ \\
\hline Sakha 69 & Inia-RL 4220//Siete Cerros/Yaqui 50 & 2 & $5 S$ \\
\hline Sakha 92 & Napo 63/Inia 66//Wren “s” & 3 & $20 \mathrm{~S}$ \\
\hline Sakha 94 & $\begin{array}{l}\text { Opata/Rayon//KauzCMBW9043180-OTOPM-3Y-010M-010M-010Y- } \\
\text { 10M-015Y-0Y }\end{array}$ & 1,2 & 10MRMS \\
\hline Sids 1 & HD2172/Pavon “s”//1158. 57/Maya 74 “s” & 3 & $80 \mathrm{~S}$ \\
\hline Sids 12 & $\begin{array}{l}\text { BUC//7C/ALD/5MAYA74/ON//1160- } \\
\text { 147/3/BB/GLL/4/CHAT:S" /6/MAYA/VUL//CMH74A/4*SX.SD7096- } \\
\text { 4SD-1SD-1SD-0SD. }\end{array}$ & - & - \\
\hline Gemmeiza 7 & CMH74A.630/5X82/3AgentCGM.4611-2GM-3GM-1GM0GM & 4 & $20 \mathrm{~S}$ \\
\hline Gemmeiza 9 & Ald“S”/Haus//CMH74A.630/SxCGM4583-5GM-1GM-0GM. & 0,1 & 10MRMS \\
\hline Gemmeiza 10 & $\begin{array}{l}\text { Maya74“S”/ON/1160-147/3/Bb/G11/4/chat“S”/5/crow“S”CGM5820- } \\
\text { 3GM-1GM-2GM-0GM }\end{array}$ & 1 & 10MSS \\
\hline
\end{tabular}

TABLE 4: Efficacy \% of the resistance genes for leaf rust disease at seedling and adult plant stages under the Egyptian conditions.

\begin{tabular}{lcc}
\hline Lr gene & \multicolumn{2}{c}{ Efficiency \% } \\
\hline 13 & Seedling & Adult \\
19 & 27.52 & 0.00 \\
24 & 79.55 & 75.0 \\
26 & 52.07 & 25.0 \\
34 & 46.00 & 0.00 \\
37 & 64.22 & 100.0 \\
39 & 32.82 & 50.0 \\
46 & - & 85.0 \\
\hline
\end{tabular}

where PCR-based markers are already available for almost half of the 60 or more designated resistance genes and alleles. Furthermore, all the effective resistance genes designated so far can be traced in segregating progeny populations by means of MAS.

The genes Lr13, Lr24, Lr34, and Lr36 were the most common resistance genes that could be identified in the cultivars. $L r 13$ is probably the most widely distributed $L r$ gene in the world [20]. 58\% of the European wheat genotypes tested carried Lr13 alone or in combination [21]. The gene was once considered to confer durable adult plant resistance but is now ineffective in several countries including Mexico [8]. Lr13 is still considered effective in combinations with other race-specific genes in Australia as the Lr13-virulent pathotype was avirulent on many other resistance genes [22]. However, in Egypt pathotypes contain virulence to Lr13 in combination with virulence on several important resistance genes and many vars. that carries Lr13 alone or in combination with other genes were susceptible in the field trails. As expected Lr34 was found in all tested cultivars, although this gene alone is capable of reducing the level of infection to almost half, as reported by [23]; resistance that is both excellent and durable can only be achieved if $\operatorname{Lr} 34$ is combined with 2 or 3 other genes [24].

Lr24 and Lr26 genes were identified in the tested cultivars but were not effective in Egypt. The resistance gene Lr26 is present on the rye segment in a T1BL-1RS wheat-rye translocation. The cultivars "Brigadier," "Florida," "Haven" and "Toronto," show infection types corresponding to Lr26 and carry the T1BL-1RS translocation [25]. Moreover, it has become clear that virulence to Lr26 exists in Northern Europe [26]. Gene Lr37 showed intermediate resistance in Egypt. Gene Lr37 confers mainly adult plant resistance and is difficult to detect in seedling tests. The cultivars that seemed to carry Lr37 singly provided low seedling resistance and full adult plant resistance in Western Europe in 1996-1999 [22].

Most of the resistance genes included in the present study were detected in the Egyptian cultivars. The presence of Lr13 and Lr19 was confirmed by specific amplification of single fragments 324 and $300 \mathrm{bp}$. The resistance reaction to the rust pathotypes revealed the presence of $\operatorname{Lr} 19$ gene. Similarly, rust resistance genes $L r 24$ and $L r 26$ resulted in the amplification of the expected fragments 100 and $260 \mathrm{bp}$. The other resistance genes $\operatorname{Lr} 34,35,36,37,39$ and 46 show specific amplification fragments of 253, 252, 282, 199, 180, and $335 \mathrm{bp}$, respectively. 


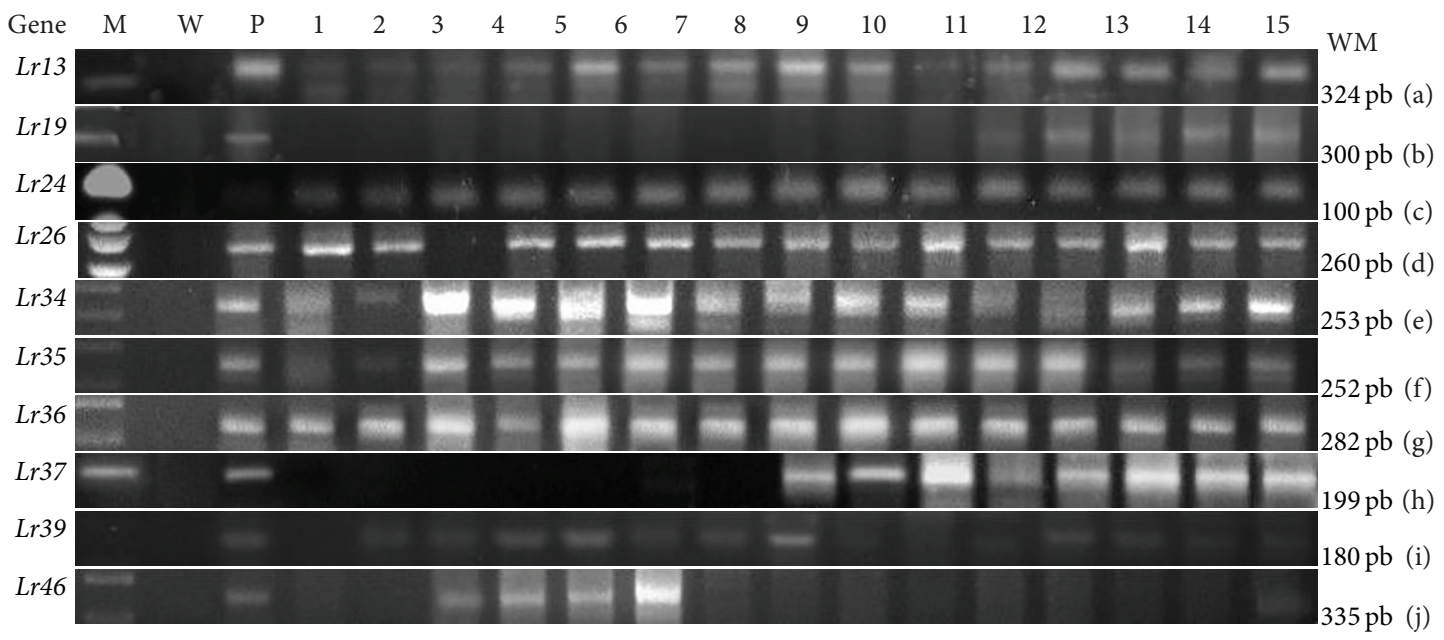

FIGURE 1: PCR amplification of 15 cultivars genomic DNA using ten $L r$ molecular marker. Lane M, 100pb marker; lane W, water as negative control; P, positive control; lane 1 Giza 163 cv, lane 2 Giza 164; lane 3, Giza 165; lane 4, Giza 167; lane 5, Giza 168; lane 6, Sakha 8; lane 7, Sakha 61, lane 8, Sakha 69; lane 9, Sakha 92; lane 10, Sakha 94; lane 11, Sids 1; lane 12, Sids 12; lane 13, Gemmeiza 7; lane 14, Gemmeiza 9, lane 15, Gemmeiza 10. (a) Lr13, (b) Lr19, (c) Lr24, (d) Lr26, (e) Lr34, (f) Lr35, (g) Lr36, (h) Lr37, (i) Lr39 and (j) $\operatorname{Lr} 46$.

TABLE 5: Presence of resistance genes to leaf rust in the wheat cultivars used.

\begin{tabular}{|c|c|c|c|c|c|c|c|c|c|c|}
\hline \multirow{2}{*}{ Cultivar } & \multicolumn{10}{|c|}{$L r$ genes } \\
\hline & 13 & 19 & 24 & 26 & 34 & 35 & 36 & 37 & 39 & 46 \\
\hline Giza 163 & + & - & + & + & + & + & + & - & - & - \\
\hline Giza 164 & + & - & + & + & + & + & + & - & + & - \\
\hline Giza 165 & + & - & + & - & + & + & + & - & + & + \\
\hline Giza 167 & + & - & + & + & + & + & + & - & + & + \\
\hline Giza 168 & + & - & + & + & + & + & + & - & + & + \\
\hline Sakha 8 & + & - & + & + & + & + & + & - & - & + \\
\hline Sakha 61 & + & - & + & + & + & + & + & - & + & - \\
\hline Sakha 69 & + & - & + & + & + & + & + & + & + & - \\
\hline Sakha 92 & + & - & + & + & + & + & + & + & - & - \\
\hline Sakha 94 & + & - & + & + & + & - & + & + & - & - \\
\hline Sids 1 & + & + & + & + & + & + & + & + & - & - \\
\hline Sids 12 & + & + & + & + & + & + & + & + & + & - \\
\hline Gemmeiza 7 & + & + & + & + & + & + & + & + & + & - \\
\hline Gemmeiza 9 & + & + & + & + & + & + & + & + & + & - \\
\hline Gemmeiza 10 & + & + & + & + & + & + & + & + & + & - \\
\hline
\end{tabular}

(+) presence of gene; (-) absence of gene.

Leaf rust resistance gene $\operatorname{Lr} 19$ has linkage with stem rust resistance gene Sr25 and a gene that causes yellowness of wheat flour [20].

The Lr24 gene is known to be linked to the Sr24 gene for resistance to stem rust, which is apparently effective against all races of stem rust [6] of study paving the way for marker-aided selection of rust resistance genes. The utility of such studies is further authenticated by other studies, where the presence of rust resistance genes was confirmed with molecular markers [27, 28]. Marker-assisted selection offers the opportunity to select desirable lines on the basis of genotype rather than phenotype, especially in the case of combining different genes in a single genotype. With the help of molecular marker, the pyramiding of leaf rust resistance genes, which are active at the seedling and/or adult stage, should facilitate more efficient breeding for durable resistance against this disease. The mechanism for durable resistance to leaf rust is poorly understood, but durability appears to be enhanced when genes are combined [29].

Experience gained so far suggests that markers flanking Lr genes can be used simply and effectively in marker-assisted backcross programmers. Nevertheless, as the linkage between markers and resistance genes is not complete, regular phenotypic monitoring will be required if satisfactory parental genotypes are to be selected. According to our earlier results [30] the ratio of false positive plants for the genes $\operatorname{Lr} 9, \operatorname{Lr} 24$, Lr25, and $\operatorname{Lr} 29$ were 1.3, 4.0, 9.5, and 7.6\%, respectively. However, molecular markers can prove the presence of the 
requested resistance gene in the genetic background and in the case of plants carrying adult plant resistance genes like Lr35 and Lr37 this is the only way to choose appropriate parents for crossing programmer. The use of MAS, whereby breeders select molecular markers linked to $\mathrm{Lr}$ genes, enables the pyramiding of more than one effective resistance gene. With the help of molecular markers, resistance genes are easy to detect in wheat varieties of unknown parentage. This information can then be used to design crossing programmers.

\section{Conflict of Interests}

The authors declare that there is no conflict of interests regarding the publication of this paper.

\section{Acknowledgment}

The authors would like to extend their appreciation to the Deanship of the Scientific Research at King Saud University for its funding of this research through the Research Group Project no. RGP-VPP-269.

\section{References}

[1] R. F. Park, C. R. Wellings, and H. S. Bariana, "Preface to 'global landscapes in cereal rust control,' Australian Journal of Agricultural Research, vol. 58, no. 6, p. 469, 2007.

[2] M. Kassem, A. El-Ahmed, M. S. Hakim, M. El-Khaliefa, and M. Nachit, "Identification of prevalent races of Puccinia triticina Eriks. in Syria and Lebanon," Arab Journal Plant Protection, vol. 29, no. 1, pp. 7-13, 2011.

[3] M. Al Naimi, S. Hakim, M. Nachit, and A. Y. Yah, "Multiple disease resistance in durum wheat (Triticum turgidum L. var. durum)," in Durum Wheat Improvement in the Mediterranean Region: New Challenges, C. Royo, M. Nachit, N. Difonzo, and J. L. Araus, Eds., pp. 387-392, CIHEAM, Zaragoza, Spain, 2000.

[4] D. Samsampour, B. M. Zanjani, J. K. Pallavi et al., "Identification of molecular markers linked to adult plant leaf rust resistance gene $L r 48$ in wheat and detection of $L r 48$ in the Thatcher nearisogenic line with gene Lr25," Euphytica, vol. 174, no. 3, pp. 337342, 2010.

[5] T. Schnurbusch, E. Bossolini, M. Messmer, and B. Keller, "Tagging and validation of a major quantitative trait locus for leaf rust resistance and leaf tip necrosis in winter wheat cultivar Forno," Phytopathology, vol. 94, no. 10, pp. 1036-1041, 2004.

[6] D. R. Knott, The Wheat Rust-Breeding for Resistance. Monographs on Theoretical and Applied Genetics, vol. 12, Springer, Berlin, Germany, 1989.

[7] A. E. Melchinger, "Use of molecular markers in breeding for oligogenic disease resistance," Plant Breeding, vol. 104, pp. 1-19, 1990.

[8] D. Singh, R. F. Park, and R. A. Mcintosh, "Postulation of leaf (brown) rust resistance genes in 70 wheat cultivars grown in the United Kingdom," Euphytica, vol. 120, no. 2, pp. 205-218, 2001.

[9] J. A. Kolmer, "Postulation of leaf rust resistance genes in selected soft red winter wheats," Crop Science, vol. 43, no. 4, pp. 12661274, 2003.

[10] Y. A. Wamishe and E. A. Milus, "Seedling resistance genes to leaf rust in soft red winter wheat," Plant Disease, vol. 88, no. 2, pp. 136-146, 2004.
[11] L. M. Oelke and J. A. Kolmer, "Characterization of leaf rust resistance in hard red spring wheat cultivars," Plant Disease, vol. 88, no. 10, pp. 1127-1133, 2004.

[12] A. K. Pathan and R. F. Park, "Evaluation of seedling and adult plant resistance to leaf rust in European wheat cultivars: leaf rust resistance in European wheat cultivars," Euphytica, vol. 149, no. 3, pp. 327-342, 2006.

[13] E. Soliman Nour, A. M. Abdelbacki, M. A. Najeeb, and R. I. Omara, "Geographical distribution of physiologic races of Puccinia triticina and postulation of resistance genes in new wheat cultivars in Egypt," Escience Journal Plant Pathology, vol. 1, pp. 73-80, 2012.

[14] A. M. Abdelbacki, E. Soliman Nor, M. A. Najeeb, and R. I. Omara, "Postulation and identification of resistance genes against Puccinia triticina in new wheat cultivars in Egypt using molecular markers," International Journal of Chemical, Environmental \& Biological Sciences, vol. 1, no. 1, pp. 104-109, 2013.

[15] R. P. Singh and S. Rajaram, "Resistance to Puccinia recondita f. sp. tritici in 50 Mexican bread wheat cultivars," Crop Science, vol. 31, pp. 1472-1479, 1991.

[16] E. C. Stakman, D. M. Stewart, and W. Q. Loedering, "Identification of physiologic races of Puccinia graminis f.sp. tritici," USA Agriculture Research Service Bulletin, vol. 617, p. 53, 1962.

[17] E. C. Large, "Growth stages in cereals, illustration of the feekes scale," Plant Pathology, vol. 3, pp. 128-129, 1954.

[18] M. Nazim, I. A. Imbaby, and T. M. Somaya, "Geographic distribution and virulence survey of races of Puccinia triticina f.sp. tritici leaf rust of wheat in Egypt during 2000/01-2001/02," Journal Environmental Science, vol. 79, pp. 847-864, 2003.

[19] M. Nazim, M. M. Aly, E. H. Shafik Ikhlas, and I. Abed-Malak Nagwa, "Frequency of virulence and virulence formula of wheat leaf rust races identified in Egypt during 2004/2005-2007-2008," Egyptian Journal of Phytopathology, vol. 38, pp. 77-88, 2010.

[20] R. A. McIntosh, C. R. Wellings, and R. F. Park, Wheat Rusts: An Atlas of resistAnce Genes, Kluwer Academic Publishers, Dordrecht, The Netherlands, 1995.

[21] M. Winzeler, A. Mesterhazy, R. F. Park et al., "Resistance of European winter wheat germplasm to leaf rust," Agronomie, vol. 20, no. 7, pp. 783-792, 2000.

[22] R. P. Singh and S. Rajaram, "Breeding for resistance in wheat," in Bread Wheat Improvement and Production, Plant Production and Protection, B. C. Curtis, S. Rajaram, and H. Gomez Macpherson, Eds., pp. 317-330, FAO, Rome, Italy, 2002.

[23] R. P. Singh and S. Rajaram, "Genetics of adult-plant resistance of leaf rust in 'frontana' and three CIMMYT wheats," Genome, vol. 35, no. 1, pp. 24-31, 1992.

[24] S.-C. Hysing, R. P. Singh, J. Huerta-Espino, A. Merker, E. Liljeroth, and O. Diaz, "Leaf rust (Puccinia triticina) resistance in wheat (Triticum aestivum) cultivars grown in Northern Europe 1992-2002," Hereditas, vol. 143, no. 2006, pp. 1-14, 2006.

[25] S. Larsson, J. Hagman, and D. Borjesdotter, Strasad, Trindsad, Oljevaxter: Sortval, Sveriges Lantbruk-Suniversitet, Faltforskningsenheten, 2003.

[26] O. Robert, F. Dedryver, M. Leconte, B. Rolland, and C. de Vallavieille-Pope, "Combination of resistance tests and molecular tests to postulate the yellow rust resistance gene Yr17 in bread wheat lines," Plant Breeding, vol. 119, no. 6, pp. 467-472, 2000.

[27] Ł. Stępień, L. Golka, and J. Chełkowski, "Leaf rust resistance genes of wheat: identification in cultivars and resistance sources," Journal of Applied Genetics, vol. 44, no. 2, pp. 139-149, 2003. 
[28] D. V. McVey and D. L. Long, "Genes for leaf rust resistance in hard red winter wheat cultivars and parental lines," Crop Science, vol. 33, no. 6, pp. 1373-1381, 1993.

[29] D. L. Long, A. P. Roelfs, K. J. Leonard, and J. J. Roberts, "Virulence and diversity of Puccinia recondita f.sp. tritici in the United States in 1992," Plant Disease, vol. 78, no. 9, pp. 901-906, 1994.

[30] M. Gál, G. Vida, A. Uhrin, Z. Bedo, and O. Veisz, "Incorporation of leaf rust resistance genes into winter wheat genotypes using marker-assisted selection," Acta Agronomica Hungarica, vol. 55, no. 2, pp. 149-156, 2007.

[31] R. Seyfarth, C. Feuillet, G. Schachermayr, M. Messmer, M. Winzeler, and B. Keller, "Molecular mapping of the adult-plant leaf rust resistance gene Lr13 in wheat (Triticum aestivum L.)," Journal of Genetics and Breeding, vol. 54, no. 3, pp. 193-198, 2000.

[32] R. Prins, J. Z. Groenewald, G. F. Marais, J. W. Snape, and R. M. D. Koebner, "AFLP and STS tagging of Lr19, a gene conferring resistance to leaf rust in wheat," Theoretical and Applied Genetics, vol. 103, no. 4, pp. 618-624, 2001.

[33] G. M. Schachermayr, M. M. Messmer, C. Feuillet, H. Winzeler, M. Winzeler, and B. Keller, "Identification of molecular markers linked to the Agropyron elongatum-derived leaf rust resistance gene Lr24 in wheat," Theoretical and Applied Genetics, vol. 90, no. 7-8, pp. 982-990, 1995.

[34] V. Mohler, S. L. K. Hsam, F. J. Zeller, and G. Wenzel, "An STS marker distinguishing the rye-derived powdery mildew resistance alleles at the $\mathrm{Pm} 8 / \mathrm{Pm} 17$ locus of common wheat," Plant Breeding, vol. 120, no. 5, pp. 448-450, 2001.

[35] M. William, R. P. Singh, J. Huerta-Espino, S. Ortiz Islas, and D. Hoisington, "Molecular marker mapping of leaf rust resistance gene Lr46 and its association with stripe rust resistance gene Yr29 in wheat," Phytopathology, vol. 93, no. 2, pp. 153-159, 2003.

[36] J. Gold, D. Harder, F. Townley-Smith, T. Aung, and J. Procunier, "Development of a molecular marker for rust resistance genes Sr39 and Lr35 in wheat breeding lines," Electronic Journal of Biotechnology, vol. 2, no. 1, pp. 35-40, 1999.

[37] N. A. Dadkhodaie, H. Karaoglou, C. R. Wellings, and R. F. Park, "Mapping genes Lr53 and Yr35 on the short arm of chromosome $6 \mathrm{~B}$ of common wheat with microsatellite markers and studies of their association with Lr36," Theoretical and Applied Genetics, vol. 122, no. 3, pp. 479-487, 2011.

[38] M. Helguera, I. A. Khan, J. Kolmer, D. Lijavetzky, L. Zhong-qi, and J. Dubcovsky, "PCR assays for the Lr37-Yr17-Sr38 cluster of rust resistance genes and their use to develop isogenic hard red spring wheat lines," Crop Science, vol. 43, no. 5, pp. 1839-1847, 2003.

[39] W. J. Raupp, S. Singh, G. L. Brown-Guedira, and B. S. Gill, "Cytogenetic and molecular mapping of the leaf rust resistance gene Lr39 in wheat," Theoretical and Applied Genetics, vol. 102, no. 2-3, pp. 347-352, 2001. 

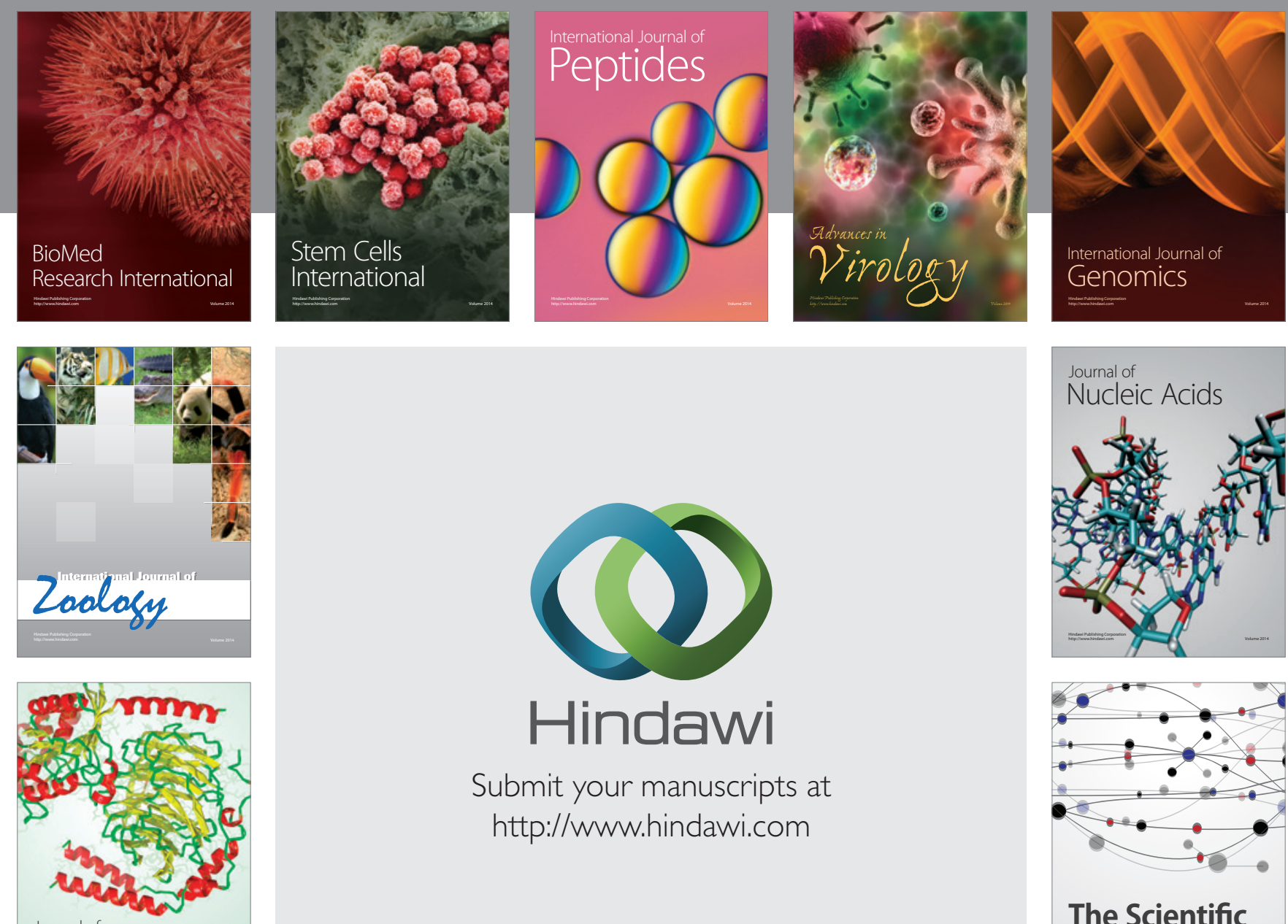

Submit your manuscripts at

http://www.hindawi.com

Journal of
Signal Transduction
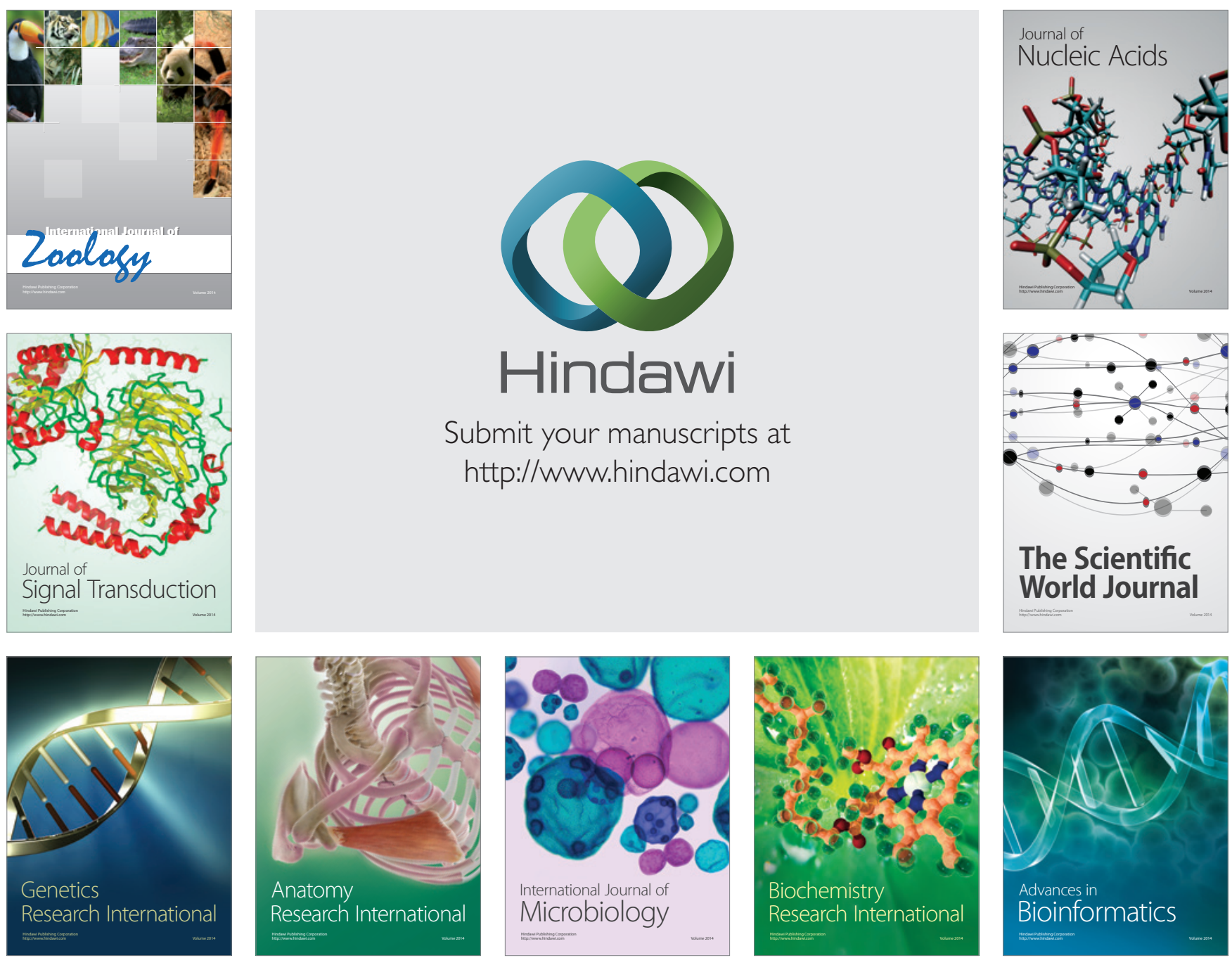

The Scientific World Journal
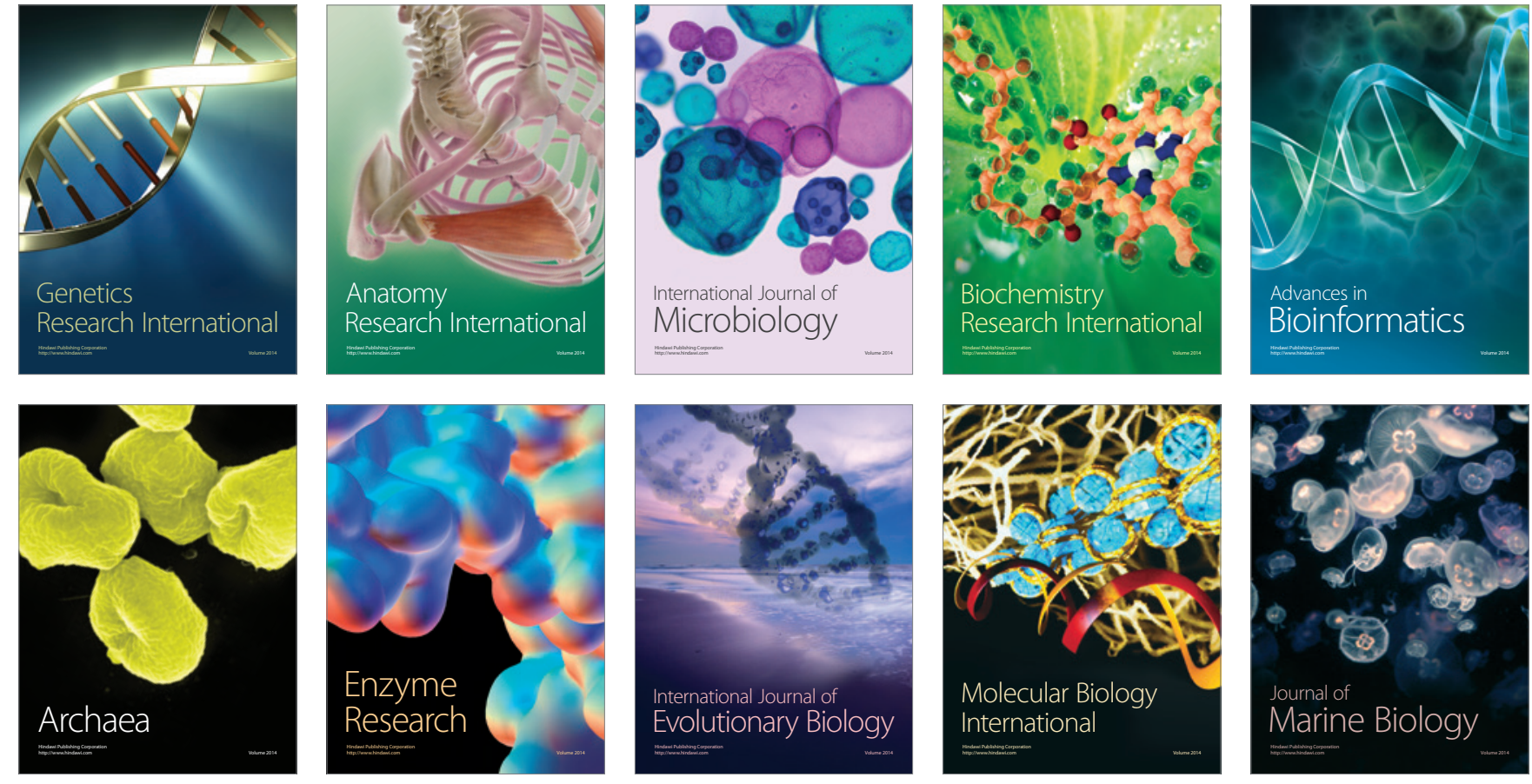